\title{
Mineralogical, Geochemical and Physico-Chemical Characterization of Clay Raw Materials from Three Clay Deposits in Northern Cameroon
}

\author{
B. P. Kagonbé1,2*, D. Tsozué1, A. N. Nzeukou ${ }^{1}$, S. Ngos III ${ }^{3}$ \\ ${ }^{1}$ Department of Earth Sciences, Faculty of Science, University of Maroua, Maroua, Cameroon \\ ${ }^{2}$ Local Materials Authority Promotion (MIPROMALO), Yaoundé, Cameroon \\ ${ }^{3}$ Faculty of Mine, Petroleum, Gas and Water Resources Exploration, University of Maroua, Kaélé, Cameroon \\ Email: *kagonbebertin@gmail.com
}

How to cite this paper: Kagonbé, B. P., Tsozué, D., Nzeukou, A. N., \& Ngos III, S. (2021). Mineralogical, Geochemical and Physico-Chemical Characterization of Clay Raw Materials from Three Clay Deposits in Northern Cameroon. Journal of Geoscience and Environment Protection, 9, 86-99. https://doi.org/10.4236/gep.2021.96005

Received: March 1, 2021

Accepted: June 18, 2021

Published: June 21, 2021

Copyright (c) 2021 by author(s) and Scientific Research Publishing Inc. This work is licensed under the Creative Commons Attribution International License (CC BY 4.0).

http://creativecommons.org/licenses/by/4.0/

\begin{abstract}
The characterization of clay raw materials of three clay deposits from Northern Cameroon was investigated. The three deposits, located in Gaschiga, Sekandé and Boulgou, are locally used as building materials, but no data are available on these materials and they are relatively unknown. Mineralogical, geochemical and physico-chemical characteristics were studied, using X-ray diffraction, X-ray fluorescence and physico-chemical analyses. Mineralogically, quartz was the most abundant mineral in the studied raw materials. It is associated to abundant quantity of smectite, kaolinite and K-feldspars, and slightly abundant to traces of hematite and amphibole. Geochemically, those clayey soils are more siliceous $\left(\mathrm{SiO}_{2}, 51 \%-59 \%\right)$ with significant amount of aluminum $\left(\mathrm{Al}_{2} \mathrm{O}_{3}, 15 \%-19 \%\right)$ followed by iron oxides $\left(\mathrm{Fe}_{2} \mathrm{O}_{3}, 3 \%-10 \%\right)$. Other oxides $\left(\mathrm{K}_{2} \mathrm{O}, \mathrm{MgO}, \mathrm{TiO}_{2}, \mathrm{Na}_{2} \mathrm{O}, \mathrm{MnO}, \mathrm{CaO}\right.$ and $\left.\mathrm{P}_{2} \mathrm{O}_{5}\right)$ are in relatively lower proportion. High level of silica content explains the sandy nature of these clays. The results of granulometric analysis show that the studied raw material contain sand $(39 \%-68 \%)$ as major grain size followed by clay particles $(17 \%-38 \%)$, silt $(1 \%-36 \%)$ and gravels $(0 \%-16 \%)$. The studied clayey soils were moderately plastic, with plasticity index values ranging from $13 \%$ to $30 \%$, and are also characterized by very high liquidity limits of $34 \%-63 \%$.
\end{abstract}

\section{Keywords}

Clay Material, Characterization, Mineralogical, Physico-Chemical, North-Cameroon 


\section{Introduction}

Clay is a widely distributed abundant mineral resource of major industrial importance for an enormous variety of uses (Ampian, 1985; Reeves et al., 2006; Murray, 2007). According to Velde (1983) clay is applied both to materials having a particle size of less than $2 \mu \mathrm{m}$ and to the family of minerals that has similar chemical compositions and common crystal structural characteristics. This material also has the power to be shaped, to shrink, to harden after drying and to consolidate after firing, which allows the formation of a vitreous phase more or less important (Melo et al., 2003; Kamseu et al., 2007; Pialy, 2009). They have varying chemical composition depending on both the physical and chemical changes in the environment where clay deposits are found (Salawudeen et al., 2010). In the context of sustainable development and technological innovation relative to the field of futuristic research, the study of clay and its properties for various applications appears as an imperative. Clay deposits have been identified in all regions in Cameroon (Sieffermann, 1959; Nkoumbou et al., 2001; Mefire et al., 2015; 2018; Basga et al., 2018; Nchare et al., 2018; Nzeukou et al., 2021) though with differing properties probably owing to geological differences. It is the reason why many houses in cities and villages are built using these materials due to the social and economic factors. In the North Cameroon for example, clay materials are mainly used for the manufacture of different pottery items and building materials such as bricks (Djenabou et al., 2015; Temga et al., 2015; 2018; Tsozué et al., 2017; Yanné et al., 2018; Nguiamba et al., 2019; Nzeukou et al., 2021; Yaboki et al., 2021). These activities, practiced by craftsmen during the dry season, bring them finances to meet their needs. While the consumption of these products tends to become widespread, their production remains very unsustainable in some developing countries. This situation can be explained by the virtual absence of a real industrial fabric and a poor estimation of the local resources potential. Therefore, the evaluation of this natural resource has an important effect on the economic development of countries. The exploration of new clay deposits in developing countries such as Cameroon could significantly contribute to socio-economic development, as this helps also identifying the original materials. Many factors intervene in all industrial applications of clay material. They include their structure, composition and physical properties. This paper aims to characterize the clay raw materials collected from three clay deposits in the northern part of the Cameroon. In detail, it will be to characterize the clay raw material on the mineralogical, geochemical and physico-chemical composition view point. The results of the work will be used to improve a database to support the start-up of industrial projects for local clay materials.

\section{Materials and Methods}

\subsection{Study Area}

The study area is located at the center of the Benue valley in North Cameroon, between latitudes $10^{\circ} 10^{\prime}$ and $9^{\circ} 30^{\prime \prime} \mathrm{N}$ and longitudes $13^{\circ} 15^{\prime}$ and $13^{\circ} 46^{\prime} \mathrm{E}$ (Figure 
1). The study was undertaken in three localities, Gaschiga, Sekandé and Boulgou (Table 1). They were chosen mainly for their traditional used as building materials. The climate is characterized by a Sudanian climate, with two contrasted seasons: a humid one from May to October and a dry one from November to April. Total yearly precipitations vary between 900 and $1500 \mathrm{~mm}$ and mean annual temperature is $28^{\circ} \mathrm{C}$. The general landscape is composed of two geomorphological units, extensive plain whose monotony is interrupted here and there

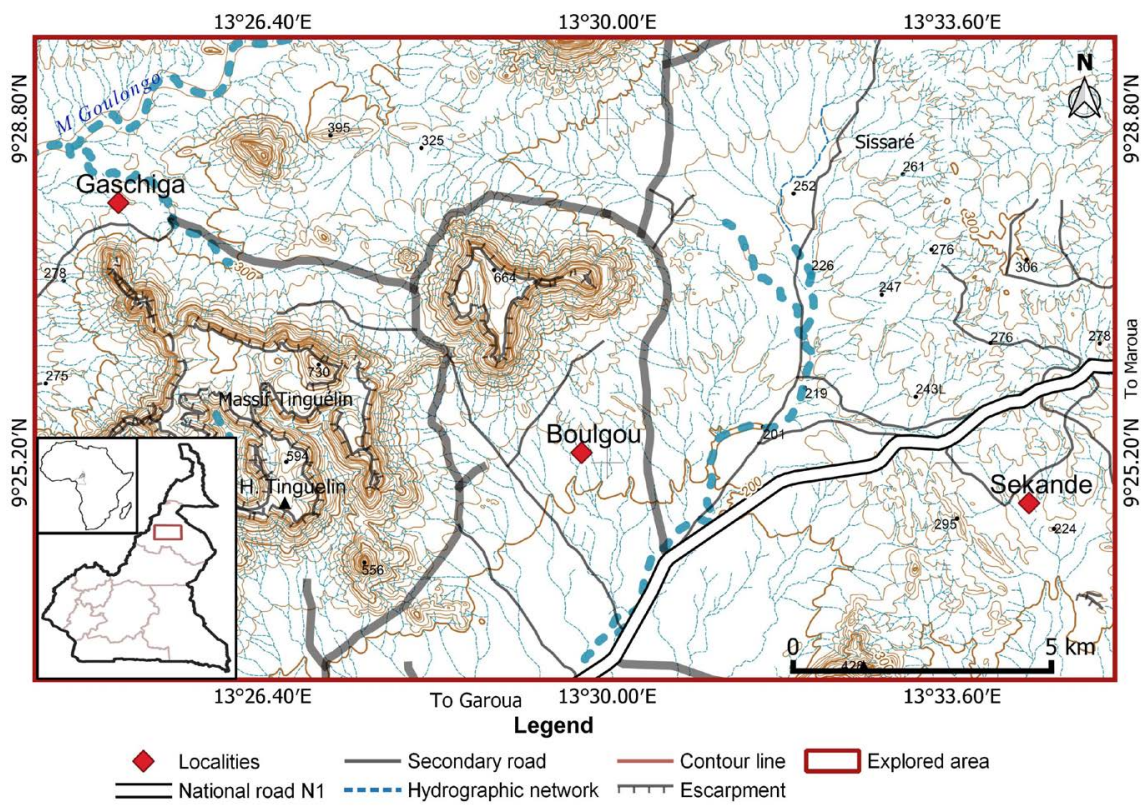

Figure 1. Location of the study area.

Table 1. Geographical coordinates of the sampling points.

\begin{tabular}{|c|c|c|c|c|}
\hline $\mathrm{N}^{\bullet}$ & Profile & Sampling code & Geographic coordinates & Explored site \\
\hline 1 & GA1 & GA1C2 & $09^{\circ} 25^{\prime} 41.5^{\prime \prime} \mathrm{N} ; 13^{\circ} 24^{\prime} 00.6^{\prime \prime} \mathrm{E}$ and $271 \mathrm{~m}$ & \\
\hline 2 & GA1 & GA2C2 & $09^{\circ} 26^{\prime} 47.4^{\prime \prime} \mathrm{N} ; 13^{\circ} 23^{\prime} 26.3^{\prime \prime} \mathrm{E}$ and $239 \mathrm{~m}$ & Gaschiga \\
\hline 3 & GA1 & $\mathrm{GA} 3 \mathrm{C} 2$ & $09^{\circ} 26^{\prime} 20.6^{\prime \prime N} ; 13^{\circ} 23^{\prime} 36.6^{\prime \prime E}$ and $256 \mathrm{~m}$ & \\
\hline 4 & SK1 & SK1C2 & $09^{\circ} 24^{\prime} 57.2^{\prime \prime} \mathrm{N} ; 13^{\circ} 32^{\prime} 02.1^{\prime \prime} \mathrm{E}$ and $223 \mathrm{~m}$ & \\
\hline 5 & SK1 & SK1C3 & $09^{\circ} 24^{\prime} 57.2^{\prime \prime} \mathrm{N} ; 13^{\circ} 32^{\prime} 02.1^{\prime \prime} \mathrm{E}$ and $223 \mathrm{~m}$ & \\
\hline 6 & SK2 & SK2C2 & $09^{\circ} 24^{\prime} 50.9^{\prime \prime} \mathrm{N} ; 13^{\circ} 32^{\prime} 55.6^{\prime \prime} \mathrm{E}$ and $228 \mathrm{~m}$ & Sekandé \\
\hline 7 & SK3 & SK3C2 & $09^{\circ} 24^{\prime} 59.7^{\prime \prime N} ; 13^{\circ} 31^{\prime} 58.8^{\prime \prime E}$ and $226 \mathrm{~m}$ & \\
\hline 8 & SK4 & SK4C3 & $09^{\circ} 24^{\prime} 34.9^{\prime \prime} \mathrm{N} ; 13^{\circ} 37^{\prime} 52.1^{\prime \prime E}$ and $230 \mathrm{~m}$ & \\
\hline 9 & $\mathrm{BO} 1$ & $\mathrm{BO} 1 \mathrm{C} 2$ & $09^{\circ} 25^{\prime} 37.0^{\prime \prime} \mathrm{N} ; 13^{\circ} 28^{\prime} 25.0^{\prime \prime E}$ and $241 \mathrm{~m}$ & \\
\hline 10 & $\mathrm{BO} 2$ & $\mathrm{BO} 2 \mathrm{C} 2$ & $09^{\circ} 25^{\prime} 56.2^{\prime \prime N} ; 13^{\circ} 28^{\prime} 03.1^{\prime \prime E}$ and $259 \mathrm{~m}$ & \\
\hline 11 & $\mathrm{BO} 3$ & $\mathrm{BO} 3 \mathrm{C} 2$ & $09^{\circ} 24^{\prime} 54.3^{\prime \prime} \mathrm{N} ; 13^{\circ} 28^{\prime} 36.4^{\prime \prime} \mathrm{E}$ and $229 \mathrm{~m}$ & Boulgou \\
\hline 12 & BO5 & $\mathrm{BO} 5 \mathrm{C} 2$ & $09^{\circ} 24^{\prime} 36.5^{\prime \prime} \mathrm{N} ; 13^{\circ} 28^{\prime} 60.1^{\prime \prime E}$ and $210 \mathrm{~m}$ & \\
\hline 14 & // & SPmG & $09^{\circ} 26^{\prime} 06.2^{\prime \prime} \mathrm{N} ; 13^{\circ} 27^{\prime} 12.6^{\prime \prime} \mathrm{E}$ and $420 \mathrm{~m}$ & \\
\hline
\end{tabular}


by small hills or "inselbergs". The inselbergs, 200 to $800 \mathrm{~m}$ a.s.l., are characterized by gentle to steep slopes. The substratum is made by Meso to Neoproterozoic gneissic basement and continental sediments (sandstones) of the Middle to Upper Cretaceous age (Ngounouno et al., 2001; 2003) (Figure 2). The vegetation is a seasonally flooded prairie which is strongly modified by farming activities (Letouzey, 1980). The superficial formations are mainly constituted of vertisols associated with ferruginous soils (Raunet, 2003; Tamfuh et al., 2011; 2018; Kagonbé et al., 2020a).

\subsection{Sampling}

Field work was carried out during the dry season and consisted of direct observations, description of environmental settings and soil survey in order to choose the position of pits. Table 1 outlines the profile code, sampling code and their geographic coordinate. Eleven pits were dug in three localities (Gaschiga, Sekandé and Boulgou) and thirteen samples were collected: five in Sekandé (SK1C2, SK1C3, SK2C2, SK3C2 and SK4C3), three in Gaschiga (GA1C2, GA2C2 and $\mathrm{GA} 3 \mathrm{C} 2$ ) and five in Boulgou (BO1C2, BO2C2; $\mathrm{BO} 3 \mathrm{C} 2, \mathrm{BO} 5 \mathrm{C} 2$ and $\mathrm{SPmG}$ (Table 1). The samples were selected on the basis of their color and homogeneity. About $30 \mathrm{~kg}$ of each sample were collected and placed in polythene bags, labeled and sent to the laboratory for analyses.

\subsection{Analytical Techniques}

Mineralogical and geochemical analyses were done at the Research Unit Clay, Geochemistry and Sedimentary Environments (AGEs) of the University of Liege in Belgium. X-ray diffraction patterns were obtained with a diffractometer (Bruker Advance 8) equipped with $\mathrm{Ni}$ filtered $\mathrm{CuKa}$ radiation, with automatic slit and on-line computer control. The samples were scanned from $2^{\circ}$ to $45^{\circ} 2 \theta$. Chemical analyses were obtained by atomic absorption spectroscopy. Loss on ignition (LOI) was measured from total weight after ignition at $1000^{\circ} \mathrm{C}$ for $2 \mathrm{~h}$.

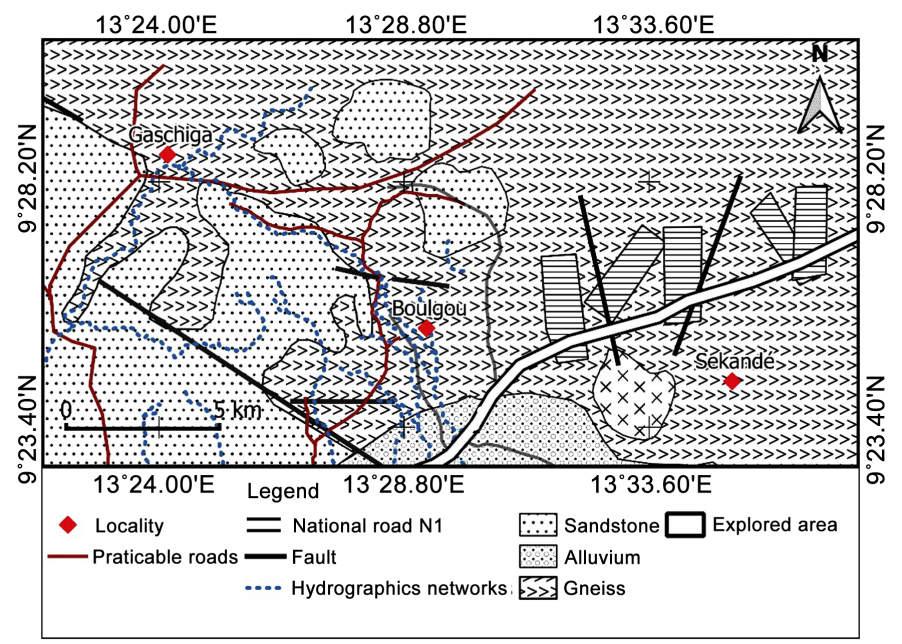

Figure 2. Geological map of the study area. 
The chemical alteration index (CAI or CIA) is considered to be a good measure for the degree of weathering (Nesbitt \& Young, 1982). Its calculation is based on molecular proportions: $\mathrm{CIA}=\mathrm{Al}_{2} \mathrm{O}_{3} /\left(\mathrm{Al}_{2} \mathrm{O}_{3}+\mathrm{CaO}^{*}+\mathrm{Na}_{2} \mathrm{O}+\mathrm{K}_{2} \mathrm{O}\right) \times 100$. In the equations, $\mathrm{CaO}^{*}$ is associated with the silicate fraction and corrected for inputs from carbonate and apatite (Ozaytekin \& Uzun, 2012). Since Al is much more immobile than the alkali elements $\left(\mathrm{Na}^{+}\right.$and $\left.\mathrm{K}^{+}\right)$and $\mathrm{Ca}^{2+}$, changes in CIA reflect changes in the proportions of feldspar and the various clay minerals developed in the clay raw materials. For the semi-quantitative analysis of the samples, the relative abundance of minerals was estimated from the intensity of the main reflections. Physico-chemical properties were determined at the laboratory of Locals Material Promotion Authority (MIPROMALO) of Yaoundé in Cameroon. The grain size distribution was determined following the NF P18-560 standard by dry sieving and the P94-057 standard by sedimentation. The plasticity was measured by the Atterberg limits: plastic limit and liquid limit according to the ASTM, D 4318-10 norms. The plasticity indices were calculated after the determination of Atterberg limits (Casagrande, 1948).

\section{Results}

\subsection{Mineralogical Composition}

The results of the mineralogical analysis on disoriented powder of thirteen samples collected are illustrated in Table 2. They show the predominance of quartz, followed by smectite, kaolinite and K-feldspar which is present in all samples of the three localities, but in various proportions. In Gaschiga, quartz is the most

Table 2. Semi-quantitative estimation, based on X-ray diffraction, of the mineralogical composition of the Gaschiga and Sekandé samples.

\begin{tabular}{|c|c|c|c|c|c|c|c|}
\hline Site & Samples & Quartz & Smectite & Kaolinite & K-feldspar & Hematite & Amphibole \\
\hline \multirow{3}{*}{ Gaschiga } & GA1C2 & ++++ & +++ & +++ & +++ & I & I \\
\hline & GA2C2 & ++++ & +++ & +++ & +++ & I & I \\
\hline & GA3C2 & +++ & +++ & +++ & +++ & I & I \\
\hline \multirow{5}{*}{ Sekandé } & SK1C2 & +++++ & +++ & ++ & +++ & I & + \\
\hline & SK1C3 & +++++ & ++ & ++ & +++ & I & ++ \\
\hline & SK2C2 & +++++ & +++ & ++ & +++ & I & ++ \\
\hline & $\mathrm{SK} 3 \mathrm{C} 2$ & +++++ & ++ & ++ & +++ & I & ++ \\
\hline & $\mathrm{SK} 4 \mathrm{C} 2$ & +++++ & ++ & ++ & +++ & I & I \\
\hline \multirow{5}{*}{ Boulgou } & $\mathrm{BO} 1 \mathrm{C} 2$ & +++++ & +++ & +++ & ++ & ++ & ++ \\
\hline & $\mathrm{BO} 2 \mathrm{C} 2$ & +++++ & ++ & +++ & ++ & ++ & ++ \\
\hline & $\mathrm{BO} 3 \mathrm{C} 2$ & +++++ & ++ & +++ & ++ & ++ & ++ \\
\hline & $\mathrm{BO} 5 \mathrm{C} 2$ & +++++ & ++ & +++ & ++ & ++ & ++ \\
\hline & SPmG & +++++ & ++ & +++ & ++ & I & 1 \\
\hline
\end{tabular}

/: none; +: traces; ++: very slightly abundant; +++: slightly abundant; ++++: abundant; +++++: very abundant. 
abundant mineral followed in the same proportion by smectite, kaolinite and K-feldspar. In Sekandé, quartz is also the main mineral, but highly expressed here than in Gaschiga. It is followed by smectite and kaolinite which quantities on contrary are lower. K-feldspar remains in the same proportion as in Gaschiga. In Boulgou, quartz remains the most represented mineral. Contrary to the two other sites, kaolinite is the most important mineral here after quartz. It is followed by smectite and K-feldspar, which quantities are globally low compared to the two other sites. The Boulgou site stands out from other sites by the presence of hematite, which quantities are similar to those of smectite. Also, amphibole, another primary mineral, is present in the study area. It is observed only in Sekandé and Boulgou.

\subsection{Geochemical Composition}

The geochemical composition of the clay samples is illustrated in Table 3. The results show that the most abundant oxides are silica $\left(\mathrm{SiO}_{2}\right)$ followed by alumina $\left(\mathrm{Al}_{2} \mathrm{O}_{3}\right)$, iron $\left(\mathrm{Fe}_{2} \mathrm{O}_{3}\right)$ and potassium $\left(\mathrm{K}_{2} \mathrm{O}\right) . \mathrm{SiO}_{2}$ ranged from $53 \%$ to $59 \%$ in Gaschiga, $50 \%$ to $59 \%$ in Sekandé and $51 \%$ to $58 \%$ in Boulgou. It is followed by $\mathrm{Al}_{2} \mathrm{O}_{3}$, which quantities vary between $15 \%$ to $18 \%$ in Gaschiga, $17 \%$ to $20 \%$ in Sekandé and $15 \%$ to $18 \%$ in Boulgou. $\mathrm{Fe}_{2} \mathrm{O}_{3}$ quantities are low in Gaschiga and range between $3 \%$ to $6 \%$. At Sekandé and Boulgou, its proportions range between $6 \%-10 \%$ and $5 \%-8 \%$ respectively. These three main oxides are followed by $\mathrm{K}_{2} \mathrm{O}$ and $\mathrm{MgO} . \mathrm{K}_{2} \mathrm{O}$ proportions range from $1 \%-3 \%, 0.2 \%-3 \%$ and $2 \%-3 \%$ in Gaschiga, Sekandé and Boulgou respectively. $\mathrm{MgO}$ proportions are also low, with values globally ranging between $0.98 \%$ and $2.89 \%$ in all the study sites. $\mathrm{CaO}$ and $\mathrm{Na}_{2} \mathrm{O}$ proportions are also low. They range globally between $0 \%$ and $3.75 \%$ for $\mathrm{CaO}$ and $0.56 \%$ and $2.59 \%$ for $\mathrm{Na}_{2} \mathrm{O}$. The proportions of $\mathrm{P}_{2} \mathrm{O}_{5}, \mathrm{TiO}_{2}$ and $\mathrm{MnO}$ are very low, with values below $1.68 \%$. The loss of ignition, an important indicator of the weathering degree is high, ranging between $6 \%$ to $15 \%$. The $\mathrm{SiO}_{2} / \mathrm{Al}_{2} \mathrm{O}_{3}$ ratio was $>2 \%$, indicative of an excess of $\mathrm{SiO}_{2}$ in the studied clays. The sum of $\mathrm{TiO}_{2}+\mathrm{Fe}_{2} \mathrm{O}_{3}+\mathrm{CaO}+\mathrm{MgO}+\mathrm{Na}_{2} \mathrm{O}+\mathrm{K}_{2} \mathrm{O}$ is high. Its values vary between $9.91 \%$ and $20.23 \%$. The chemical index of alteration (CIA) ranged globally between $67.20 \%$ and $87.30 \%$, indicating that the studied clay deposits are constituted of very weathered raw material (Table 3). It is noted however that the most weathered material is observed in Sekandé.

\subsection{Physico-Chemical Properties}

Table 4 summarizes the physicochemical characteristics of the different samples. Globally, the result reveals that the particle size distribution varying slightly between different studied localities. The proportions of particles more than $2 \mathrm{~mm}$ in size, vary from $17 \%$ - 33\% for Gaschiga, 26\% - 38\% for Sekandé and 20\% $32 \%$ for Boulgou. Clay fraction has the medium quantities. Silt fraction has the lowest quantities in Boulgou. They range between $1 \%$ to $8 \%$. In Gaschiga and Sekandé their values vary from $11 \%$ to $36 \%$ and $11 \%$ to $16 \%$ respectively. Sand is 
B. P. Kagonbé et al.

Table 3. Major elements and loss on ignition (LOI) of the studied clays.

\begin{tabular}{|c|c|c|c|c|c|c|c|c|c|c|c|c|}
\hline \multirow{2}{*}{$\begin{array}{c}\text { Samples/major } \\
\text { elements }\end{array}$} & \multicolumn{4}{|c|}{ Gaschiga } & \multicolumn{4}{|c|}{ Sekandé } & \multicolumn{4}{|c|}{ Boulgou } \\
\hline & GA1C2 & $\mathrm{GA} 2 \mathrm{C} 2$ & GA3C2 & SK1C2 & SK1C3 & SK2C2 & SK3C2 & SK4C3 & BO1C2 & $\mathrm{BO} 2 \mathrm{C} 2$ & $\mathrm{BO} 3 \mathrm{C} 2$ & $\mathrm{BO} 5 \mathrm{C} 2$ \\
\hline $\mathrm{SiO}_{2}$ & 54.20 & 53.20 & 59.25 & 56.92 & 59.84 & 50.68 & 52.34 & 55.39 & 58.60 & 51.76 & 58.90 & 57.29 \\
\hline $\mathrm{Al}_{2} \mathrm{O}_{3}$ & 15.78 & 18.02 & 18.55 & 17.96 & 17.51 & 19.77 & 18.05 & 20.33 & 16.00 & 18.50 & 15.19 & 16.73 \\
\hline $\mathrm{Fe}_{2} \mathrm{O}_{3}$ & 3.46 & 6.02 & 6.10 & 6.92 & 6.27 & 9.16 & 10.07 & 8.10 & 6.13 & 8.54 & 6.83 & 5.66 \\
\hline $\mathrm{K}_{2} \mathrm{O}$ & 3.13 & 1.94 & 1.61 & 0.20 & 0.61 & 2.26 & 2.34 & 3.20 & 2.64 & 2.24 & 3.26 & 2.86 \\
\hline $\mathrm{MgO}$ & 1.25 & 2.35 & 1.96 & 1.74 & 1.65 & 2.77 & 4.48 & 1.42 & 0.98 & 1.45 & 2.89 & 1.24 \\
\hline $\mathrm{TiO}_{2}$ & 0.05 & 0.04 & 0.06 & 0.84 & 0.73 & 1.16 & 0.92 & 0.99 & 1.11 & 1.68 & 1.39 & 1.31 \\
\hline $\mathrm{P}_{2} \mathrm{O}_{5}$ & 0.27 & 0.35 & 0.04 & 0.28 & 0.25 & 0.01 & 0.26 & 0.94 & 0.24 & 0.42 & 0.41 & 0.19 \\
\hline $\mathrm{CaO}$ & 0.17 & 0.57 & 1.84 & 1.69 & 1.12 & 1.85 & 0.55 & 0.00 & 2.78 & 3.75 & 1.56 & 2.91 \\
\hline $\mathrm{Na}_{2} \mathrm{O}$ & 1.85 & 1.40 & 1.74 & 0.97 & 0.82 & 1.14 & 0.56 & 0.99 & 2.27 & 2.57 & 2.59 & 2.18 \\
\hline $\mathrm{MnO}$ & 0.26 & 0.41 & 0.06 & 0.05 & 0.05 & 0.07 & 0.07 & 0.78 & 0.08 & 0.09 & 0.13 & 0.08 \\
\hline LOI & 15.87 & 14.99 & 7.53 & 10.27 & 12.00 & 10.86 & 10.09 & 8.48 & 6.97 & 7.44 & 6.42 & 7.94 \\
\hline Total & 96.29 & 99.29 & 98.74 & 97.84 & 100.85 & 99.73 & 99.73 & 100.62 & 97.78 & 98.44 & 99.57 & 98.39 \\
\hline $\mathrm{SiO}_{2} / \mathrm{Al}_{2} \mathrm{O}_{3}$ & 3.43 & 2.95 & 3.19 & 3.16 & 3.41 & 2.56 & 2.89 & 2.72 & 3.65 & 2.79 & 3.87 & 3.42 \\
\hline CIA & 75.39 & 82.20 & 78.14 & 86.30 & 87.30 & 79.02 & 84.00 & 82.91 & 67.60 & 68.40 & 67.20 & 67.80 \\
\hline $\mathrm{TiO}_{2}+\mathrm{Fe}_{2} \mathrm{O}_{3}+$ & & & & & & & & & & & & \\
\hline $\begin{array}{c}\mathrm{CaO}+\mathrm{MgO}+ \\
\mathrm{Na}_{2} \mathrm{O}+\mathrm{K}_{2} \mathrm{O}\end{array}$ & 9.91 & 12.32 & 13.31 & 12.36 & 11.2 & 18.34 & 18.92 & 14.7 & 15.91 & 20.23 & 18.52 & 16.16 \\
\hline
\end{tabular}

Table 4. Physico-chemical characteristics of the studied clays.

\begin{tabular}{|c|c|c|c|c|c|c|c|c|c|}
\hline Site & Sample & $\begin{array}{c}\text { Organic } \\
\text { matter } \\
(\%)\end{array}$ & $\begin{array}{c}\text { Gravel } \\
(\%) \\
\Phi>2 \mathrm{~mm}\end{array}$ & $\begin{array}{c}\text { Sand (\%) } \\
2>\Phi>0.02 \mathrm{~mm}\end{array}$ & $\begin{array}{c}\text { Silt (\%) } \\
0.02>\Phi>0.002 \mathrm{~mm}\end{array}$ & $\begin{array}{c}\text { Clay (\%) } \\
\Phi<0.002 \mathrm{~mm}\end{array}$ & $\begin{array}{l}\text { Liquid } \\
\text { limit } \\
(\%)\end{array}$ & $\begin{array}{c}\text { Plastic } \\
\text { limit } \\
(\%)\end{array}$ & $\begin{array}{c}\text { Plasticity } \\
\text { index } \\
(\%)\end{array}$ \\
\hline \multirow{3}{*}{ Gaschiga } & GA1C2 & 5.39 & 2.80 & 43.10 & 36.30 & 17.80 & 63.40 & 36.90 & 26.50 \\
\hline & GA2C2 & 3.82 & 7.50 & 45.30 & 17.30 & 29.90 & 60.70 & 30.80 & 29.90 \\
\hline & GA3C2 & 6.98 & 4.60 & 49.90 & 11.90 & 33.60 & 48.00 & 30.30 & 17.70 \\
\hline \multirow{5}{*}{ Sekandé } & SK1C2 & 5.98 & 5.80 & 45.50 & 15.20 & 33.50 & 50.90 & 24.40 & 26.50 \\
\hline & SK1C3 & 4.57 & 3.01 & 50.00 & 16.20 & 30.70 & 55.70 & 27.00 & 28.70 \\
\hline & SK2C2 & 4.35 & 8.50 & 53.20 & 11.90 & 26.40 & 43.50 & 24.50 & 19.00 \\
\hline & SK3C2 & 6.40 & 8,80 & 39.70 & 15.30 & 36.20 & 60.90 & 32.70 & 28.20 \\
\hline & SK4C3 & 4.71 & 1.70 & 48.00 & 12.00 & 38.30 & 55.80 & 25.80 & 30.00 \\
\hline \multirow{5}{*}{ Boulgou } & $\mathrm{BO} 1 \mathrm{C} 2$ & 3.02 & 16.00 & 50.00 & 1.00 & 26.00 & 43.20 & 22.50 & 20.70 \\
\hline & $\mathrm{BO} 2 \mathrm{C} 2$ & 2.31 & 5.00 & 59.00 & 8.00 & 20.00 & 34.10 & 20.30 & 13.80 \\
\hline & ВО3C2 & 2.68 & 2.00 & 68.00 & 8.00 & 22.00 & 38.10 & 24.80 & 13.30 \\
\hline & BO5C2 & 2.07 & 0.00 & 59.00 & 5.00 & 36.00 & 36.00 & 18.10 & 18.00 \\
\hline & SPmG & 3.45 & 7.00 & 65.93 & 7.00 & 20.43 & 56.50 & 23.50 & 33.10 \\
\hline
\end{tabular}

the most important fraction. Its quantities are $43 \%$ to $50 \%$ in Gaschiga, $39 \%$ $50 \%$ in Sekandé and 50\% - 68\% in Boulgou. The higher proportions are observed in Boulgou. 
The gravels are slightly represented in clay raw material. Their quantities vary from $0 \%$ to $16 \%$. Only BO1C2 presents the higher value. The presence of organic matter in a raw material is inconvenient and undesirable. Organic compounds particularly reduce the strength of a building material. They cause corrosion and softening in the material over time. Their proportions vary between $2 \%$ to $6 \%$. The liquid limit of studied samples ranged between $36 \%$ and $63 \%$ (Table 4; Figure 3), while the plastic limit values were between $18 \%$ and $36 \%$. The highest plastic value ( $\mathrm{LL}>63 \%$ ) was observed in the GA1C2 sample. The resulting plasticity indexes ranged between $17 \%$ and $33 \%$.

\section{Discussion}

The mineralogical analysis of the studied clayey materials is characterized by relatively high contents of quartz followed by smectite, kaolinite and K-feldspar, with small proportions of amphibole observed in Sekandé and Boulgou, as well as hematite only observed in Boulgou. Except the GA3C2 sample coming from Gaschiga, the proportion of quartz is very abundant in all localities. Smectite clay mineral was responsible for the extensive swelling and shrinking upon drying and wetting, the major characteristic of all vertisols (Duchaufour, 1977; Soil Survey Staff, 1999; FAO, 2006; Aydinalp, 2010). The high smectite content in the studied clay material was related to the low landscape positions, a strongly contrasted climate and the presence of a clay-rich alluvial parent material (Boulvert, 1968; Bocquier, 1973; Gavaud, 1975; Duchaufour, 1977). The predominance of smectite suggests that the chemical process acting in the study area is bisiallitisation (Pédro, 1966; Temga et al., 2015). All the studied clay bodies are rich in quartz and kaolinite which suggest felsic sources. Kaolinite is formed by the

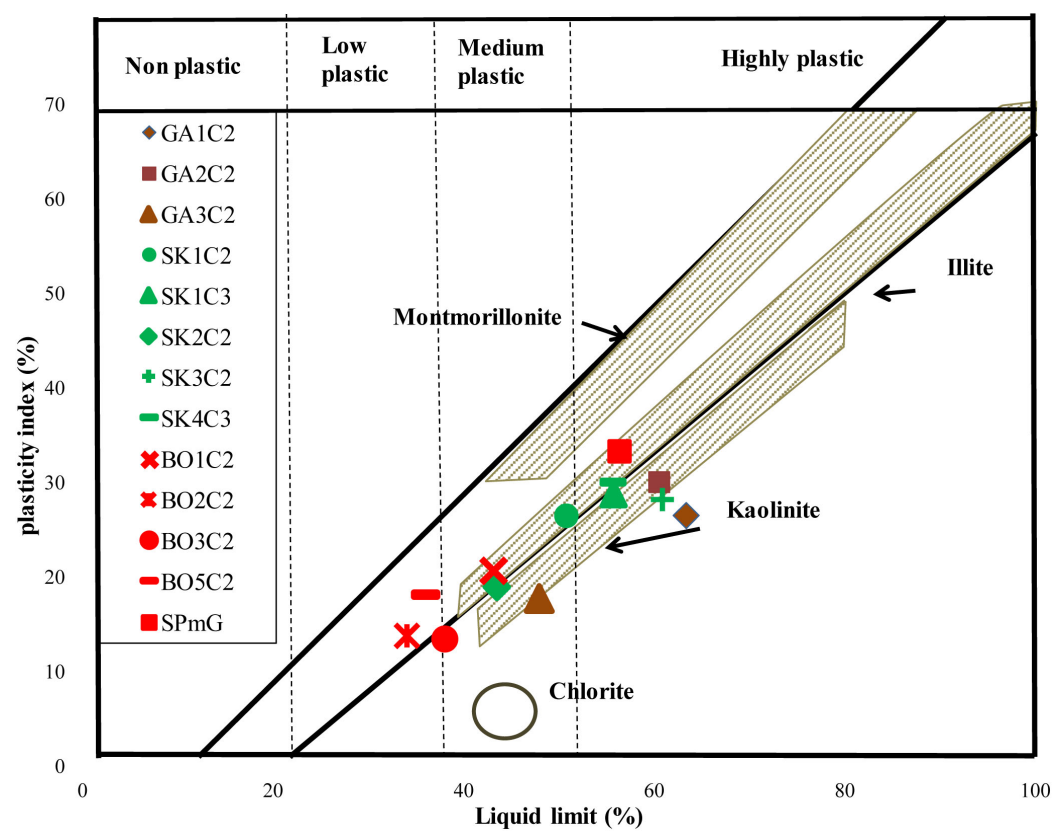

Figure 3. Casagrand's plasticity chart (Holtz \& Kovacs, 1981) showing representative clay material samples. 
decomposition of orthoclase feldspar in granite (Nzeukou et al., 2021; Yaboki et al., 2021). The existence of hematite in the Boulgou is tributary to the significant iron oxide contents $\mathrm{Fe}_{2} \mathrm{O}_{3}$, is in line with the presence of amphibole. The presence of kaolinite suggests that monosiallitisation is a crystallochemical processes acting in the study area towards bisiallitisation (Pédro, 1966).

The studied clayey materials are characterized by relatively high contents of $\mathrm{SiO}_{2}$ followed by $\mathrm{Al}_{2} \mathrm{O}_{3}$ and $\mathrm{Fe}_{2} \mathrm{O}_{3}$. However, it also contains some minor elements such as potassium, sodium and titanium oxides. The $\mathrm{SiO}_{2}$ content should be associated with the presence of quartz particles: a highest value for all sample refers to the higher sand fraction in particle size distribution analysis and higher quartz content in mineral composition. Alumina $\left(\mathrm{Al}_{2} \mathrm{O}_{3}\right)$ reflects the presence of aluminosilicates. Iron $\left(\mathrm{Fe}_{2} \mathrm{O}_{3}\right)$ is related to the presence of hematite while potassium $\left(\mathrm{K}_{2} \mathrm{O}\right)$ is binded to the presence k-feldspars (Nzeukou et al., 2021). The high $\mathrm{SiO}_{2} / \mathrm{Al}_{2} \mathrm{O}_{3}$ ratio $>2 \mathrm{wt} \%$, suggests the presence of free-form of silica and 2:1 clay mineral types (Crook, 1974; Temga et al., 2015) and indicates high chemical maturity of the investigated samples (Maignien, 1958; Tsozué et al., 2017; Temga et al., 2015). A representation in the triangular diagram $\mathrm{SiO}_{2}-\mathrm{Al}_{2} \mathrm{O}_{3}-\mathrm{Fe}_{2} \mathrm{O}_{3}$ showed that all sample were localized on $\mathrm{SiO}_{2}-\mathrm{Al}_{2} \mathrm{O}_{3}$ axis (Figure 4), toward $\mathrm{SiO}_{2}$ pole in line with high $\mathrm{SiO}_{2} / \mathrm{Al}_{2} \mathrm{O}_{3}$ ratio. This is indicative of an excess of $\mathrm{SiO}_{2}$ in the studied soils and confirmed the presence of quartz and 2:1 phyllosilicates of montmorillonite type (Tsozué et al., 2017).

The suitability of clays for different industrial applications is based on their particle size distribution. Particle size distribution of clay plays an essential role in defining the properties of suspensions (plasticity and viscosity) and green pastes during drying and firing (Rivi \& Ries, 1997; Basga et al., 2018). Grain-size distribution also affects the microstructure and the mechanical properties of fired materials (Ngun et al., 2011; Nguiamba et al., 2019; Sayouba et al., 2019; Temga et al., 2015; Voula et al., 2021). The particle size distribution of the study clay is moderately consisted of clay fraction and mostly sand fraction. Indeed, the particle size distribution of the studied clays shows that the samples are constituted of mixtures in varied proportions. Position of different samples in ternary diagram for textures illustrated by Figure 5 shows that the dominant soil texture for Boulgou was sandy silt and heavy sandy silt for Sekandé and Gaschiga excepted GA1C2. The dominance of the coarse range could be attributed to the immediate environment especially from weathering and disintegration products of sandstone (Kagonbé et al., 2020b; Voula et al., 2021). The Atterberg limits of the studied samples are shown in the Holtz and Kovacs (1981) diagram (Figure 3). Based on this diagram, samples $\mathrm{BO} 2 \mathrm{C} 2, \mathrm{BO} 3 \mathrm{C} 2$ and $\mathrm{BO} 5 \mathrm{C} 2$ are lower plastic clays, samples $\mathrm{BO} 1 \mathrm{C} 2, \mathrm{SK} 2 \mathrm{C} 2, \mathrm{SK} 1 \mathrm{C} 2$ and $\mathrm{GA} 3 \mathrm{C} 2$ are medium plastic, while samples SK3C2, SK4C3, SK1C3, SPmG, GA2C2 and GA1C2 are higher plasticity clays. According to McNally (1998), the plasticity of clay materials depends to its particle size distribution and mineralogy composition. This characteristic could be also attributed to the low organic matter content and the dominance of the kaolinite mineral in the clay (Abdullahi et al., 2012). 


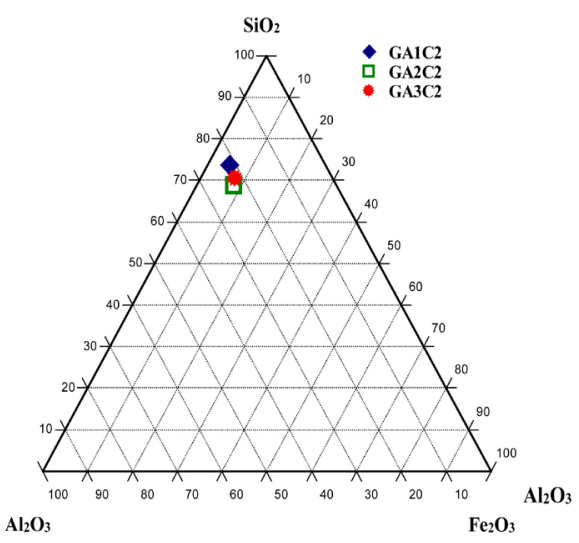

(a)

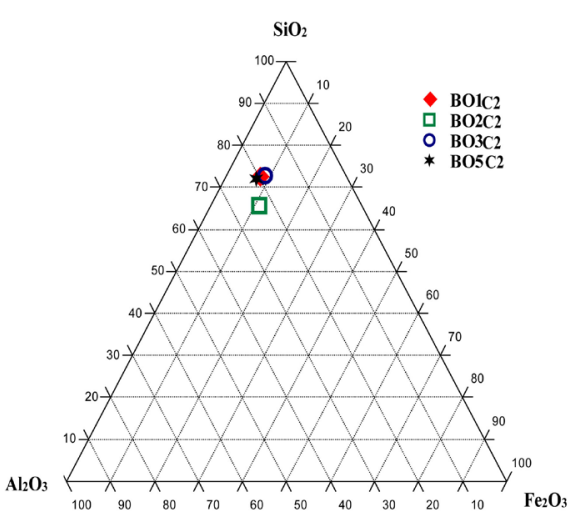

(c)

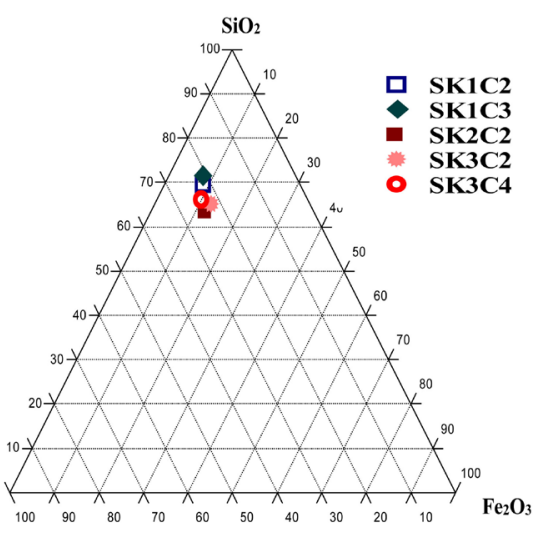

(b)

Figure 4. Geochemical composition of the studied soils in $\mathrm{SiO}_{2}-\mathrm{Al}_{2} \mathrm{O}_{3}-\mathrm{Fe}_{2} \mathrm{O}_{3}$ diagram, (a) Gaschiga; (b) Sekandé and (c) Boulgou.

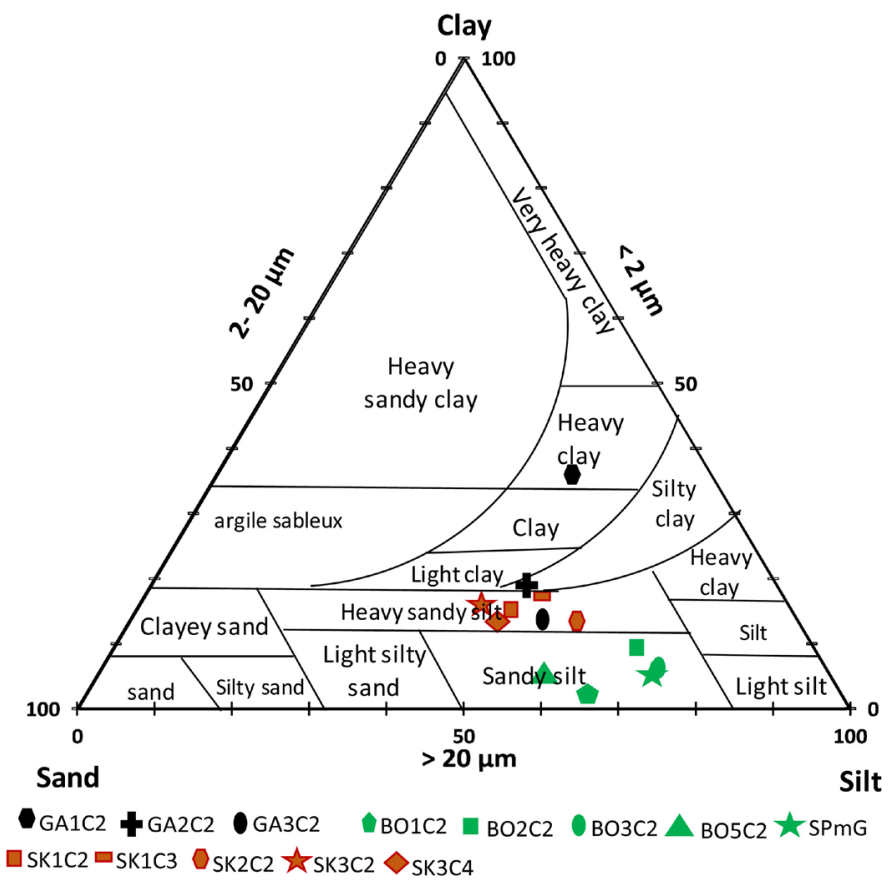

Figure 5. Ternary diagram of the studied clay materials samples according to Richer de Forges et al. (2008). 


\section{Conclusion}

In this study, geochemical, mineralogical and physico-chemical properties of the raw clayey materials from Gaschiga, Sekandé and Boulgou in Northern Cameroon were investigated. Mineralogically, the studied raw clay materials are constituted of smectite and kaolinite as secondarily clay minerals, associated to high amount of quartz, and small amount of hematite, K-feldspath and amphibole. Monosiallitisation and bisiallitisation are the two crystallochemical processes acting in the study area. Geochemically, $\mathrm{SiO}_{2}, \mathrm{Al}_{2} \mathrm{O}_{3}$ and $\mathrm{Fe}_{2} \mathrm{O}_{3}$ are the main oxides. $\mathrm{Al}_{2} \mathrm{O}_{3}$ reflects the presence of aluminosilicates and $\mathrm{Fe}_{2} \mathrm{O}_{3}$ is related to the presence of hematite. High $\mathrm{SiO}_{2} / \mathrm{Al}_{2} \mathrm{O}_{3}$ ratio indicates an excess of $\mathrm{SiO}_{2}$ in the form of quartz and the presence of 2:1 phyllosilicates of montmorillonite type towards kaolinite. Particle size analysis shows that the raw materials are mostly constituted of sand fraction (39\% - 68\%), followed by clay fraction (17\% - 38\%) and silt fraction $(1 \%-36 \%)$. The clay materials are moderately plastic clays, with plasticity characteristics varying between $18 \%$ and $36 \%$ and plasticity index ranging between $13 \%$ and $30 \%$, which could be attributed to the low organic matter content and the dominance of the kaolinite mineral in the raw clay materials.

\section{Conflicts of Interest}

The authors declare no conflicts of interest regarding the publication of this paper.

\section{References}

Abdullahi, Y., Ali, E. A., \& Oyeyemi S. (2012). A Study of the Physico-Chemistry and Mineralogy of Agbaja Clay for Its Industrial Application. Chemical Journal, 3, 53-60.

Ampian, S. G. (1985). Clays. In: Mineral Facts and Problems (Vol. 675, pp. 1-13). US Bureau of Mines Bulletin, Washington DC: US Bureau of Mines.

Aydinalp, C. (2010). Some Important Properties and Classification of Vertisols under Mediterranean Climate. African Journal of Agriculture Research, 6, 449-452.

Basga, D. S., Tsozué, D., Temga, J. P., Balna J., \& Nguetnkam, J. P. (2018). Land Use Impact on Clay Dispersion/Flocculation in Irrigated and Flooded Vertisols from Northern Cameroon! International Soil and Water Conservation Research, 6, 237-244. https://doi.org/10.1016/j.iswcr.2018.03.004

Bocquier, G. (1973). Genesis and Evolution of Two Tropical Soil Toposequences in Chad, Geodynamic Interpretation. Paris: ORSTOM.

Boulvert, Y. (1968). Some Aspects of the Influence of Topography and Parent Material on the Distribution of Ferrallitic, Ferruginous and Vertisolic Soils in the Bossangoa Region of North-West Centrafrican Republic. Cah. ORSTOM, Sér. Pédol, 24, 259-275.

Casagrande, A. (1948). Classification and Identification of Soils. Transactions of the American Society of Civil Engineers, 113, 901-930.

https://doi.org/10.1061/TACEAT.0006109

Crook, K. A. W. (1974). Lithostratigraphy and Geotectonic: The Significance of Composition Variation in Flysch arenites (Graywackes). In R. H. Dott, \& R. H. Shaver (Eds.), Modern and Ancient Geosynclinal Sedimentation (Vol. 19, pp. 304-310). Tulsa, OK 
Society of Economic Paleontologists and Mineralogists. https://doi.org/10.2110/pec.74.19.0304

Djenabou, S. F., Ndjigui, P. D., \& Mbey, J. A. (2015). Mineralogical and Physicochemical Characterization of Ngaye Alluvial Clays (Northern Cameroon) and Assessment of Its Suitability in Ceramic Production. Journal of Asian Ceramic Societies, 3, 50-58. https://doi.org/10.1016/j.jascer.2014.10.008

Duchaufour, Ph. (1977). Pedogenesis and Classification of Soils. Paris: Masson.

FAO (Food and Agriculture Organization of the United Nations) (2006). World Base Reference for Soil Resources. Rome: FAO-ISRIC-IUSS.

Gavaud, M., Rieffel, J. M., \& Muller, J. P. (1975). Soils of the Benue Valley, from Lagdo to the Confluence of the Faro. Paris: ORSTOM.

Holtz, R. D., \& Kovacs, W. D., (1981). An Introduction to Geotechnical Engineering (733 p). Englewood Cliffs, NJ: Prentice Hall.

Kagonbé, B. P., Tsozué, D., Nzeukou, A. N., Basga, S. D., Belinga, R. E., Likiby, B. and Ngos III, S. (2020a). Suitability of Lateritic Soils from Garoua (North Cameroon) in Compressed Stabilized Earth Blocks Production for Low-Cost Housing Construction. Journal of Materials and Environmental Science, 11, 658-669.

Kagonbé, P.B., Tsozué, D., Djépaze, II, Y., Nzeugang, N. A., Balo, M. B., Basga, D. S., \& Ngos, III S. (2020b). Physical Characterization and Optimization of Fineness Moduli of Natural Sand from the North Region of Cameroon Used in Construction. Journal of Sustainable Construction Materials and Technologies, 5, 407-419. https://doi.org/10.29187/jscmt.2020.45

Kamseu, E., Leonelli, C., Boccaccini, D. N., Veronesi, P., Miselli, P., Pellacani, G., \& Melo, U. C. (2007). Characterization of Porcelain Compositions Using Two China Clays from Cameroon. Ceramics International, 33, 851-857. https://doi.org/10.1016/j.ceramint.2006.01.025

Letouzey, R. (1980). Phytogeographic Map of Cameron. Paris: Les Atlas Jeune Afrique.

Maignien, R. (1958). Le cuirassement des sols en Guinée, Afrique Occidentale (239 p). Thèse, Strasbourg: Université de Lorraine.

McNally, G. H. (1998). Soil and Rock Construction Materials (pp. 291-310). London: CRC Press.

Mefire Nkalih, A., Pilate, P., Yongue, R. F., Njoya, A., \& Fagel, N. (2018). Suitability of Foumban Clays (West Cameroon) for Production of Bricks and Tiles. Journal of Minerals and Materials Characterization and Engineering, 6, 244-256. https://doi.org/10.4236/jmmce.2018.62018

Mefire, A. N., Njoya, A., Fouateu, R. Y., Nsandamoun, A. T., Nzeugang, A. N., Mache, J. R., Chinje, U. M., Pilate, P., Flament, P., Siniapkine, S., Ngono, A., \& Fagel, N. (2015). Kaolin Occurrence in Koutaba (West-Cameroon): Mineralogical and Physicochemical Characterization for Ceramic Products. Clay Minerals, 50, 593-606. https://doi.org/10.1180/claymin.2015.050.5.04

Melo, C. U., Kamseu, E., \& Djangang, C. (2003). Effect of Fluxes on the Fired Properties between $950^{\circ} \mathrm{C}-1050^{\circ} \mathrm{C}$ of Some Cameroonian Clays. Bricks \& Tile International, 19, 57-69.

Murray, H. H. (2007). Applied Clay Mineralogy: Occurrences, Processing and Applications of Kaolins, Bentonites, Palygorskite-Sepiolite, and Common Clays. In H. H. Murray (Ed.). Developments in Clay Science (Vol. 2, 180 p). Amsterdam: Elsevier.

Nchare, M., Desire, E. O. B., Wang L., \& Sarki B., (2018). Mineralogical and Physicochemical Characterization of Clay in the Sangare-Paul Locality (North Cameroon), in 
Order to Assess the Potential Use in the Field of Ceramics. Open Journal of Inorganic Chemistry, 8, 71-80. https://doi.org/10.4236/ojic.2018.83006

Nesbitt, H. W., \& Young, G. M. (1982). Early Proterozoic Climates and Plate Motions Inferred from Major Element Chemistry of Lutites. Nature, 279, 715-717. https://doi.org/10.1038/299715a0

Ngounouno, I., Déruelle, B., Demaiffe, D., \& Montigny, R. (2003). Petrology of the Cenozoic volcanism in the upper Benue valley, northern Cameroon (Central Africa). Contributions to Mineralogy and Petrology, 145, 87-106. https://doi.org/10.1007/s00410-002-0438-6

Ngounouno, I., Moreau, C., Déruelle, B., Demaiffe, D., \& Montigny, R. (2001). Pétrologie du complexe alcalin sous-saturé de Kokoumi (Cameroun). Bulletin de la Société Géologique de France, 172, 675-686. https://doi.org/10.2113/172.6.675

Nguiamba, N., Belibi, P. D. B., Sieliechi, J. M., \& Ngassoum, M. B. (2019). Physico-Chemical Characterization and Stability Study in Acidic and Basic Solution of Ceramic Filters from Mouka's Clay (Cameroon). Journal of Materials Science and Chemical Engineering, 7, 42-53. https://doi.org/10.4236/msce.2019.711005

Ngun, B. K., Mohamad, H., Sulaiman, S. K., Okada, K., \& Ahmad, Z. A. (2011). Some Ceramic Properties of Clays from Central Cambodia. Applied Clay Science, 53, 33-41. https://doi.org/10.1016/j.clay.2011.04.017

Nkoumbou, C., Njoya, A., Njopwouo, D., \& Wandji, R. (2001). Intérêts économiques des matériaux argileux. In: C. Nkoumbou, \& D. Njopwouo (Eds.), Proceedings of the First Conference on the Valorisation of Clay Mineral in Cameroon (pp. 1-12). Yaoundé: University of Yaoundé I.

Nzeukou, N. A., Tsozué, D., Kagonbé, P. B., Balo, M. A., Fankam, D., Ngos III, S., Nkoumbou, C., \& Fagel, N. (2021). Clayey Soils from Boulgou (North Cameroon): Geotechnical, Mineralogical, Chemical Characteristics and Properties of Their Fired Products. SN Applied Sciences, 3, Article No. 551.

https://doi.org/10.1007/s42452-021-04541-4

Ozaytekin, H. H., \& Uzum, C. (2012). Comparison of Weathering Rates of the Soils Classiefied in Alfisol and Entisol Order developed on Limestone in the Taurus Mountains at East Mediterranean Region. Carpathian Journal of Earth and Environmental Sciences, 7, 109-120.

Pédro, G. (1966). Essai sur la caractérisation géochimique des différents processus zonaux résultant de l'altération des roches superficielles (cycle alumino-silicique). Comptes Rendus de l'Académie des Sciences Série D, 262, 1828-1831.

Pialy, P. (2009). Etude de quelques matériaux argileux du site de Lembo (Cameroun): Minéralogie, comportement au frittage et analyse des propriétés d'élasticité. Thèse de Doctorat/PhD, Limoges: Université de Limoges, Faculté des sciences et techniques.

Raunet, M. (2003). Quelques clés morphologiques pour le Nord Cameroun à l'usage des agronomes. Rapport projet ESA/SC, Cameroun, $24 \mathrm{p}$.

Reeves, G. M., Sims, J. C., \& Cripps. (2006). Clay Material Used in Construction (552 p). Special Publication No. 21, London: The Geological Society.

Richer de Forges, A., Feller, C., Jamagne, M., \& Arrouays D. (2008). Perdu dans les triangles de textures. Etudes et gestion des Sols, 15, 97-111.

Rivi, A., \& Ries, B. (1997). Single-Line Dry Grinding Technology. Ceramic World, 24, 132-141.

Salawudeen, T., Olalekan Isam, Y., Qudsieh Nassereldeen, A., Kabbashi, M. A., Suleyman, A., Muyibi, F. Y., Qusim, H., \& Shah. (2010). Effect of Modification on the Physico- 
chemical and Thermal Properties of Organophilic Clay Modified with Octadecylamine. International Journal of Engineering \& Technology IJET-IJENS, 10, 27-35.

Sayouba, K., Francois, O., Betaboale, N., Adamah, M., Jean, C. B., \& Francois, Z. (2019). Evaluation des propriétés thermo-hydro-mécaniques des briques en terre compressée (BTC) issues de la carrière de Matourkou, Burkina Faso. Afrique Science, 15, 12-22.

Sieffermann, G. (1959). Premières déterminations des minéraux argileux des sols du Cameroun. Conference Interafricaine des Sols, Dalaba, 2-11 November 1959, 139-150.

Soil Survey Staff (1999). Soil Taxonomy: A Basic System of Soil Classification for Making and Interpreting Soil Surveys, Natural Resources Conservation Service (2nd ed., 786 p). U.S. Department of Agriculture Handbook.

Tamfuh, P. A., Woumfo, E. D., Bitom, D., \& Njopwouo, D. (2011). Petrological, Physico-Chemical and Mechanical Characterization of the Topomorphic Vertisols from the Sudano-Sahelian Region of North Cameroon. The Open Geology Journal, 5, 33-55.

Temga, J. P., Balo Madi, A., Basga Djakba S., Zo’o Zame, P., Abessolo Angue, M., Mache, J. R., Nguetnkam, J. P., \& Bitom, L. D. (2018). Lime- and Sand-Stabilization of Clayey Materials from the Logone Valley (Lake Chad Basin) for Their Utilization as Building Materials. Journal of Building Engineering, 19, 472-479.

https://doi.org/10.1016/j.jobe.2018.06.003

Temga, J. P., Nguetnkam, J. P., Balo Madi, A., Basga, S. D., \& Bitom, D. L. (2015). Morphological, Physico Chemical, Mineralogical and Geochemical Properties of Vertisols Used in Bricks Production in the Logone Valley (Cameroon, Central Africa). International Research Journal of Geology and Mining, 5, 20-30.

Tsozué, D., Nzeukou, N. A., Maché, J. R., Loweh, S., \& Fagel, N. (2017). Mineralogical, Physico-Chemical and Technological Characterization of Clays from Maroua (Far-North, Cameroon) for Use in Ceramic Bricks Production. Journal of Building Engineering, 11, 17-24. https://doi.org/10.1016/j.jobe.2017.03.008

Velde, B. (1983). Diagnostic Reaction in Clays. In A. Parker, \& B. W. Sellwood (Eds.), Sediment Diagenesis (pp. 215-268). Dordrecht: Springer. 427 p. https://doi.org/10.1007/978-94-009-7259-9 4

Voula, R. M., Diamouangana, F. Z. M., Moutou, J.-M., Samba, V. I. B., Foutou, M. P., \& Ngoma, J. P. (2021). Characterization and Valuation of a Clay Soil Sampled in Londela-Kayes in the Republic of Congo. Journal of Minerals and Materials Characterization and Engineering, 9, 117-133. https://doi.org/10.4236/jmmce.2021.92009

Yaboki, E., Temga, J. P., Madi, A. B., Basga, S., Atougour, B., \& Nguetnkam, J. P. (2021). Characterization of Lithomorphic Vertisols from Kaélé (Northern Cameroon) and Their Valorization in Bricks Production. Journal of Material and Environment Sciences, 12, 353-372.

Yanné, E., Oumarou, A. A., Nde, B. D., \& Danwe, R. (2018). Physico-Chemical and Mineralogical Characterization of Two Clay Materials of the Far North Region of Cameroon (Makabaye, Maroua). Advances in Materials Physics and Chemistry, 8, 378-386. https://doi.org/10.4236/ampc.2018.89025 